\title{
Credit Supply Shocks and Economic Activity in Brazil
}

\section{Choques na Oferta de Crédito e Atividade Econômica no Brasil}

Adonias Evaristo da Costa Filho**

\begin{abstract}
This paper studies the role of credit supply shocks in Brazil, through Bayesian Vector Autoregressions (BVARs) with sign restrictions. It is found that credit supply shocks, either standalone or associated with the bank lending channel of monetary policy, lead to relatively mild effects on output growth. Despite this low sensitivity, credit supply shocks played a significant role during the 2008-2009 recession, and contributed negatively to the 2014-2016 recession.
\end{abstract}

Keywords: Credit supply. Spread. BVAR. Sign restrictions.

Resumo: Este artigo estuda os efeitos de choques na oferta de crédito no Brasil, por meio de modelos de vetores autoregressivos Bayesianos (BVAR) com restrições de sinais. Encontra-se que choques na oferta de crédito, sejam autônomos ou associados ao canal da oferta de empréstimos da política monetária, resultam em efeitos brandos no crescimento do produto. A despeito dessa baixa sensibilidade, choques na oferta de crédito tiveram um papel significativo durante a recessão de 2008-2009, e contribuíram negativamente para a recessão de 2014-2016.

Palavras-chave: Oferta de crédito. Spread. BVAR. Restrições de sinais.

JEL Classification: C32; E51; G01.

\section{Introduction}

This paper studies the impact of credit supply shocks on the Brazilian economy, following a growing empirical literature for other countries on the role of financial frictions in economic fluctuations since the Global Financial Crisis (GFC) of 2008. Although far from the epicenter of the crisis, credit spreads in Brazil increased substantially during that event, and have remained more or less stable in the last years. Considering the global nature of credit shocks (HELBLING et al., 2011), the concurrent sharp fall in real GDP at the time of the crisis suggest that credit supply shocks can lead to substantial decline in economic activity, despite the specificities of the Brazilian economy.

A better understanding of the effects of credit supply shocks can also be of interest due to the credit deepening that Brazil experienced over the last decade, with total credit to GDP climbing from 30\% in March 2007 to 47\% in August 2017,

\footnotetext{
* The views in this paper are solely the responsibility of the author and should not be interpreted as reflecting the views of the National Treasury"- STN Ordinance 833, November 28, 2018.

** Doctor in Economics - University of Brasília (UnB). Affiliations: STN and IDP. E-mail: adoniasevaristo@hotmail.com
} 
becoming more relevant for economic fluctuations. In addition to the credit deepening observed in the country, there are several reasons to seek to understand the role of credit supply shocks, since the banking system is characterized by a strong influence of earmarked credit, ${ }^{1}$ large presence of government banks, significant market concentration and limited access to external sources of funding.

A large and growing body of research documents that adverse credit supply shocks lead to sizeable and long negative effects in economic activity across countries. This paper seeks to provide evidence of such shocks for Brazil, in light of the increasing research on this topic for other countries. Empirical works for Brazil employing the same methodology of this paper are unavailable, with somehow related studies for the credit market relying on the DSGE methodology (KANCZUK, 2013; CARVALHO et al. 2018). Other studies of credit markets for Brazil have focused on the bank lending channel of monetary policy, as in Souza Sobrinho (2003), Takeda et al. (2005), Oliveira and Neto (2008), Mello and Pisu (2010), Coelho et al. (2010) and Ramos-Tallada (2015). In turn, this paper focuses on the consequences of shocks originating in the credit market for the whole economy, based on a Bayesian Vector Autoregression (BVAR) with sign restrictions, in line with related literature.

For the United States (US), Gilchrist and Zakrajsek (2012a) find that shocks in the excess bond premium - the portion of credit spreads that is not due to default risk - lead to pronounced fall in real activity, fall in bank lending and a decline in nominal interest rates in the United States. Based on a New Keynesian model augmented by the financial accelerator of Bernanke and Gertler (1999), Gilchrist and Zakrajsek (2012b) find that movements in credit spreads account well for US business cycles over the period 1985-2009.

Also for the US, Caldara and Herbst (2016) find that VARs that include credit spreads lead to a much sharper drop in real activity after a monetary policy shock relative to models that do not include credit spreads. This happens because on impact a monetary policy tightening shock induce a rise in credit spreads, which amplify the negative effect on real activity, despite the negative endogenous response of monetary policy to the rise in credit spreads.

Peersman (2012) studies the effects of bank lending shocks for the euro area, distinguishing three types of shocks: i) demand shocks to bank lending, ii) supply shocks to bank lending driven by monetary policy actions and iii) pure bank lending supply shocks, that are independent of monetary policy actions. He finds that this latter type of shocks exerts the largest impact in economic activity, explaining one-third of the forecast error variance decomposition of industrial production. As

1 Bonomo et al. (2015) using firm-level data, find that the expansion of earmarked and governmentowned bank loans after the crises was directed to older, larger and less risky firms, and that they did not stimulate investment. 
for inflation, the impact of bank lending shocks is more relevant in the long run, while negligible in the short run.

Also for the euro area, Aldasoro and Unger (2017) find that adverse bank loan supply shocks have sizeable negative consequences for economic activity, accounting for around $20 \%$ of the forecast error variance decomposition of GDP and $15 \%$ of inflation over the long run. They also find that other financing supply shocks have negligible effects on output and inflation.

Hristov et al. (2012) investigate the role of loan supply shocks in the euro area during the GFC using a panel VAR with sign restrictions. A negative loan supply shock, represented by a shock to the credit spread, leads to a fall in real GDP and in the loan volume. Loan supply shocks account for up to 10\% of GDP and inflation variability in their model.

Halvorsen and Jacobsen (2014) study the role of bank lending shocks for Norway and the UK. They find that these shocks produce sizeable consequences for real activity, more specifically for 20 and $25 \%$ of GDP volatility in Norway and UK, respectively, considering the forecast error variance decomposition in the estimated models.

Barnett and Thomas (2014) examine the role of credit supply shocks in the United Kingdom. A shock that induce a rise in credit spreads lead to a fall in GDP growth, real lending growth and an increase in inflation, which they associate with credit supply shocks being more alike aggregate supply than demand shocks. They also find that credit supply shocks in the UK account for up to half of the fall of UK GDP relative to trend since 2007.

Duchi and Elbourne (2015) study the effects of credit supply shocks in the Netherlands. They find that credit supply shocks exerted a positive contribution to GDP growth prior to the GFC, and negatively affected the economy in 2008 and 2011, around the GFC and the sovereign debt crisis in Europe, respectively.

For Canada, Atta-Mensah and Dib (2008) develop a model where lending is modeled as endogenously depending on the state of real activity. Shocks to bank lending produce a persistent fall in economic activity in Canada. The credit supply shock negatively affects the aggregate supply, inducing a rise in inflation. This is also helped by monetary policy accommodation due to drop in output. Credit supply shocks account for 10 to $17 \%$ of GDP volatility according to their findings.

Gambetti and Musso (2016) analyze the role of loan supply shocks and business cycles for the euro area, UK and US through a time-varying parameter VAR with stochastic volatility. They find a significant effect of loan supply shocks on economic activity in these areas. Loan supply shocks respond for $20 \%$ of the decline in real GDP from 2007 to 2009 in the euro area and US, and 10\% in the UK. Bijsterbosch and Falagiarday (2014) also employ a time-varying VAR for many European countries, finding that positive credit supply shocks contributed positively to eco- 
nomic growth before the GFC, negatively in 2008-2009 and with mixed outcomes after the crisis.

Following most of the aforementioned papers, the analysis for Brazil is based on VAR models under the sign restrictions identification (UHLIG, 2005). This method is particularly suitable to study the effects of credit supply shocks since it is possible to simultaneously restrict the impact of prices and quantities, i.e., a credit supply shocks is characterized by an increase in credit spreads and a fall in bank lending.

The rest of the paper is organized as follows. Section 2 presents the data used in the estimations. Section 3 describes the econometric model. Section 4 shows the results of the impulse response functions for quarterly and monthly data. Section 5 discusses the role of credit supply shocks to economic activity. Section 6 concludes.

\section{Data}

As a measure of credit spread, it is used the spread of the prime rate over the Selic policy rate. The prime rate is based on transactions with customers of large size and low credit risk, and is available since 2005, while other measures of credit spreads are available only from 2011 onwards. In addition to being the longest interest rate for credit markets available for Brazil, the prime rate has the advantage of including transactions with similar risk profile. The methodology of the prime rate was presented in the September 2011 Financial Stability Report of the Central Bank of Brazil (CBB). ${ }^{2}$

As a measure of economic activity, it is used quarterly GDP growth rates, downloaded from the CBB database (code 22109). Other variables used are the quarterly non-regulated inflation rate from IPCA (code 11428), and the Selic policy rate of the $\mathrm{CBB}$ (code 4189). The option for market prices inflation is due to the fact that an econometric analysis that include regulated prices can be misleading. Finally, as a measure of volume of credit, it is used the outstanding volume of credit to corporations, available since 2007 (code 20543). I first deflate the series, putting on prices of December 2016 and then apply the log to the real series. I then use the real credit volume outstanding at the end of each quarter. The prime rate also come from the CBB database (code 20019). The models were estimated on quarterly frequency. Figure 1 shows each series.

$2 \quad$ Available in: <http://www.bcb.gov.br/?relestab201109>. 
Figure 1 - Quarterly data

Inflation

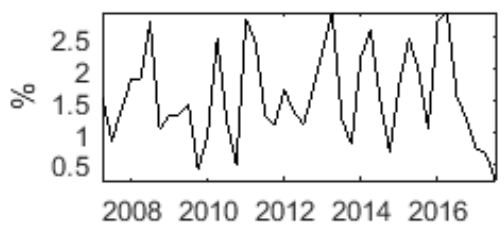

Prime Spread

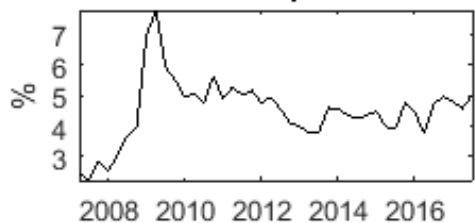

Nominal Corporate Credit

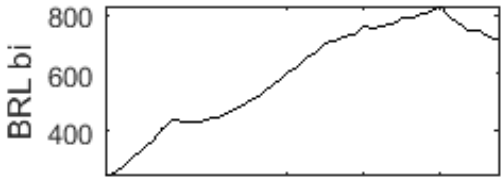

20082010201220142016

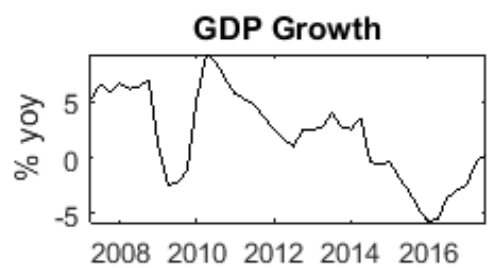

Selic Rate

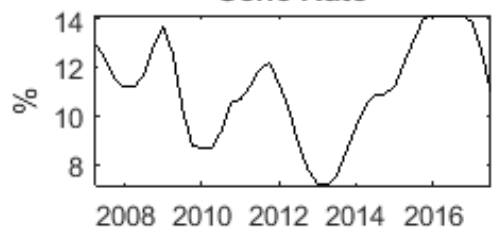

Real Corporate Credit

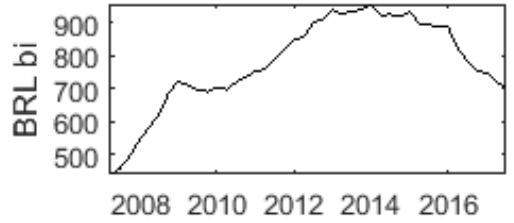

Source: Author's elaboration.

Since the prime spread is computed based on transactions with corporations, it is only analyzed credit shocks on corporations, represented by an increase in the prime spread and fall in the outstanding credit to corporations with market interest rates. Hence, it is not analyzed the consequences of credit shocks on the outstanding credit to households, as credit spreads to households are not available on the same way as the prime spread. ${ }^{3}$

\section{Model}

In line with most of the aforementioned papers, the empirical strategy relies on a BVAR with sign restrictions. The reduced form is:

$$
\mathrm{y}_{\mathrm{t}}=\mathrm{c}+\mathrm{A}_{1} \mathrm{y}_{\mathrm{t}-1}+\mathrm{A}_{2} \mathrm{y}_{\mathrm{t}-2}+\cdots+\mathrm{A}_{\mathrm{p}} \mathrm{y}_{\mathrm{t}-\mathrm{p}}+\mathrm{u}_{\mathrm{t}}
$$

where $\mathrm{y}_{\mathrm{t}}$ is a $\mathrm{n} \mathrm{x} 1$ vector containing the endogenous variables in the model and $\mathrm{u}_{\mathrm{t}}$ are reduced form residuals with zero mean and variance-covariance matrix given by $\Sigma$. The reduced form can be expressed as:

3 Despite the absence of a household spread series similar to the prime rate, the appendix show the results considering the average corporate and household spreads, which are available since 2011. 


$$
\mathrm{y}_{\mathrm{t}}=\mathrm{Bx}_{\mathrm{t}}+\mathrm{u}_{\mathrm{t}}
$$

where $B=\left[c A_{0} A_{1} A_{2} \ldots A_{p}\right]$ and $x_{t}=\left[1 y_{t-1}^{\prime} y_{t-2}^{\prime} \ldots y_{t-p}^{\prime}\right]$. The structural form is given by:

$$
\mathrm{A}_{0} \mathrm{y}_{\mathrm{t}}=\mathrm{k}+\mathrm{A}_{1}^{*} \mathrm{y}_{\mathrm{t}-1}+\mathrm{A}_{2}^{*} \mathrm{y}_{\mathrm{t}-2}+\cdots+\mathrm{A}_{\mathrm{p}}^{*} \mathrm{y}_{\mathrm{t}-\mathrm{p}}+\epsilon_{\mathrm{t}}
$$

where $\mathrm{A}_{0}$ is an $\mathrm{n} \mathrm{x} \mathrm{n}$ matrix with the contemporaneous reactions of the variables to the structural shocks, $A_{p}^{*}$ are $\mathrm{n} \times \mathrm{n}$ matrices of structural coefficients of the system, $\epsilon_{\mathrm{t}}$ is a $\mathrm{n} \times 1$ vector of shocks with $\mathrm{E}\left(\epsilon_{\mathrm{t}} \epsilon_{\mathrm{t}}^{\prime}\right)=\mathrm{I}$. The structural form and the reduced form are related through $\mathrm{A}_{0}^{-1} \mathrm{~A}_{0}^{-{ }^{-1}}=\sum$. The standard technique for imposing sign restrictions is to randomly draw orthogonal matrices $\mathrm{Q}$, such that $\mathrm{A}_{0}^{-1} \mathrm{Q}^{\prime} \mathrm{QA}_{0}$ $1^{\prime}=\sum$. By replacing $\mathrm{A}_{0}$ with $\mathrm{QA}_{0}$ in the structural form of the model, the researcher has another model that is observationally equivalent to the reduced form but with different impulse responses. If the responses from the new model satisfy the sign restrictions, the model is kept, otherwise it is discarded.

The algorithm consists in drawing the reduced form parameters $\mathrm{B}$ and $\Sigma$ from the posterior distribution of the reduced forms, draw a rotation matrix $Q$ and keep the draw if the sign restrictions are met. These steps are repeated until a sufficient number of draws from the posterior distributions are collected, conditional on the sign restrictions.

\section{Results}

This section presents the results of the estimated models, for quarterly and monthly data.

\subsection{Quarterly Data}

This section presents the results using quarterly data. The sample period is 2007Q1 to 2017Q2, 42 observations. Even though the prime rate is available from 2005 onwards, it was necessary to begin the sample in 2007, when the outstanding credit volume series begins.

The model was estimated with 2 lags and Normal-diffuse priors. Estimations were performed on the BEAR toolbox (DIEPPE et al., 2016). Each shock lasts for 2 quarters (on impact and the subsequent quarter). 95\% posterior intervals are reported in each impulse response. 
Figure 2 - Impulse response function of a credit supply shock
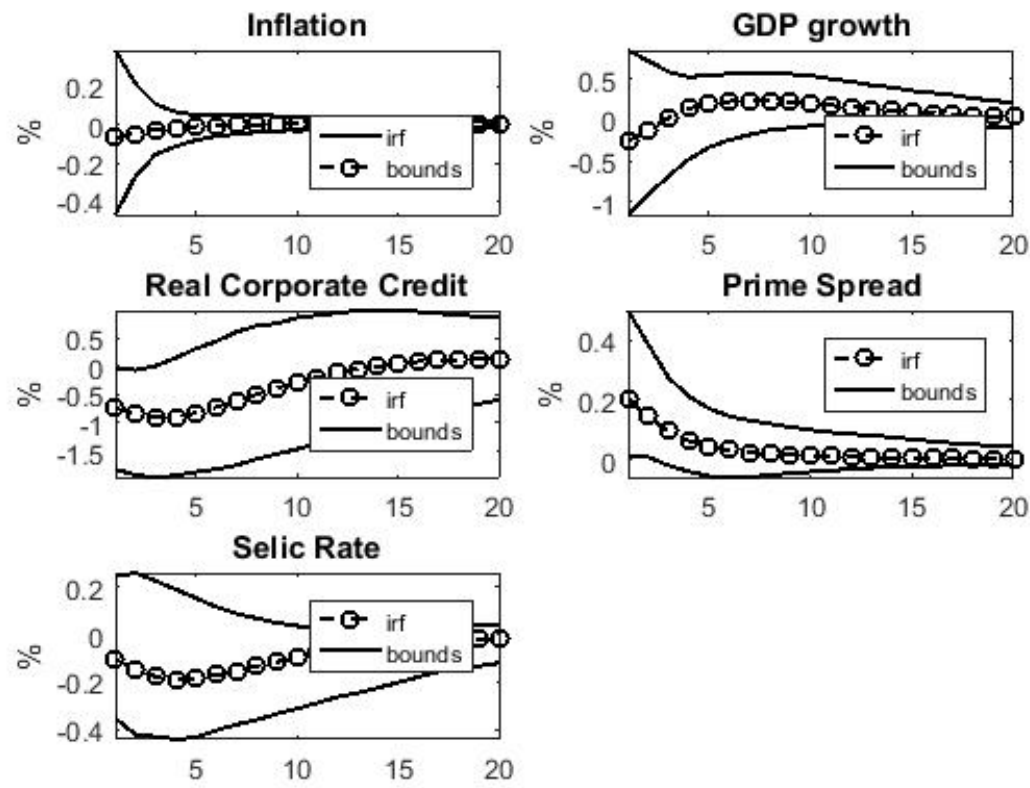

Source: Author's elaboration.

\subsubsection{Credit Supply Shocks}

Figure 2 shows the impulse response functions of a credit supply shock on the Brazilian economy, represented by a simultaneously increase in credit spreads and decline in real credit volume: A shock lead to a persistent fall in real credit, dissipating very slowly. GDP growth falls by less than $0.5 \%$ on impact, while the endogenous response of monetary policy to the shock is a modest cut in the Selic policy rate. Inflation remains almost steady. Considering the $95 \%$ confidence bands around the median, the responses of inflation, GDP and Selic rate cannot be considered statistically significant. 
Figure 3 - Impulse response function of a monetary policy shock with bank lending channel
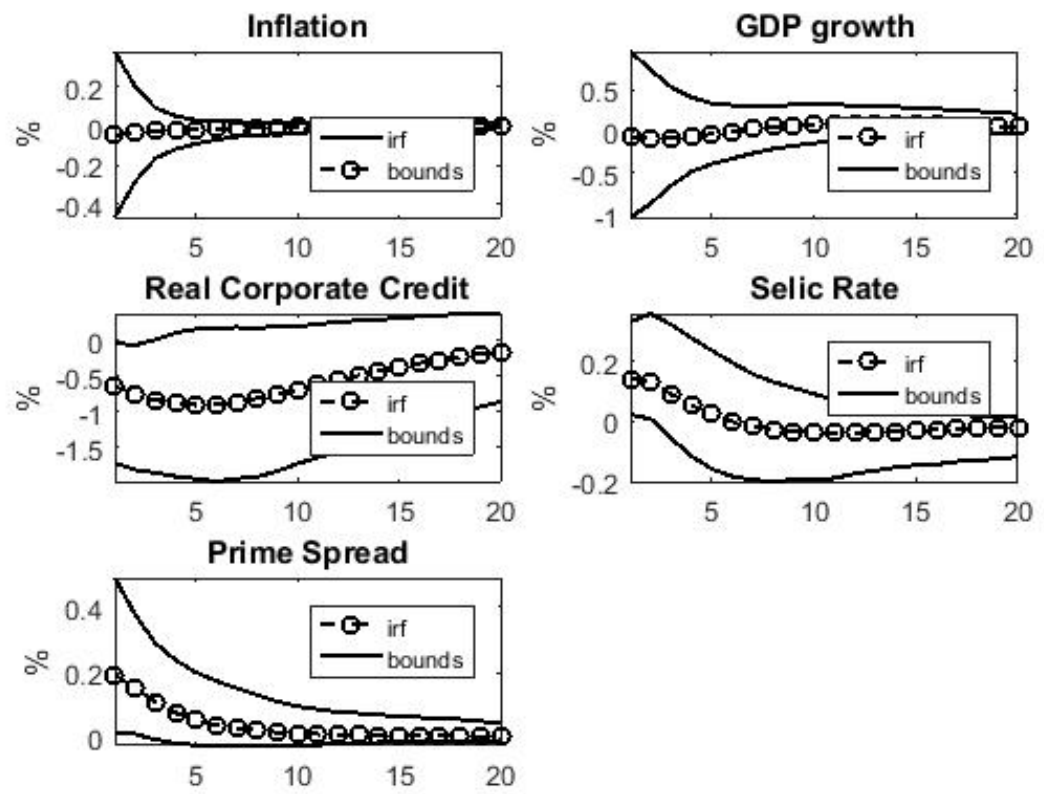

Source: Author's elaboration.

\subsubsection{Monetary Policy Shock with Bank Lending Channel}

Figure 3 shows the impulse response functions of a monetary policy shock that is accompanied by the bank lending channel. This is done imposing the restriction that after a policy tightening credit spreads increase and real credit volume declines. As in the case of pure credit supply shocks analyzed before, the restrictions are imposed only on impact and the subsequent quarter, allowing the data to speak to a maximum degree. Real credit volume falls by around $0.5 \%$ after the shock, with a protracted response to the shock, gradually dissipating. Real GDP growth does not show a strong response to the shock. The impact of the shock on inflation is negligible.

\subsubsection{Additional Shocks}

This section extends the analysis by identifying a larger number of shocks. In the previous models restrictions were placed only on the response of a shock to the prime spread and the Selic rate, in order to identify a credit supply and a monetary policy shock with bank lending channel, while the other variables in the model, namely the real credit, inflation and GDP growth, were restricted only to react 
positively to a shock to themselves. Here the model is estimated with additional restrictions, in order to identify aggregate demand and supply shocks, credit supply and demand shocks and monetary policy shocks. The sign restrictions placed in each variable to identify the shocks are shown on Table 1. Aggregate demand shocks move inflation and GDP in the same direction, with the opposite happening for aggregate supply shocks. Conversily, credit demand shocks lead to a positive comovement between spreads and credit volume, with the opposite happening for credit supply. Finally, monetary policy shocks are identified with a negative response of inflation and GDP growth to a shock on the Selic rate. Figure 4 shows the impulse responses of this model, which was again estimated from 2007Q1 to 2017Q2, with 2 lags.

An aggregate demand shock, shown in the first column, is followed by an increase in real credit. The Selic rate increases endogenously, as in a Taylor rule. There is a fall in the prime rate, for which there is no clear explanation. An aggregate supply shock, presented in the second column, is followed by a gradual increase in the credit to corporations. The response of the Selic and the prime rate is negligible. The impulse response after a credit supply shock, on the fourth column, is quite similar to that presented earlier. Finally, a monetary policy shock, shown in the last column, induce a modest increase in the prime rate, with the credit volume slowly declining.

Table 1 - Sign restrictions on impulse response functions

\begin{tabular}{cccccc}
\hline Shock & $\begin{array}{c}\text { Aggregate } \\
\text { Demand }\end{array}$ & $\begin{array}{c}\text { Aggregate } \\
\text { Supply }\end{array}$ & $\begin{array}{c}\text { Credit } \\
\text { Demand }\end{array}$ & $\begin{array}{c}\text { Credit } \\
\text { Supply }\end{array}$ & $\begin{array}{c}\text { Monetary } \\
\text { Policy }\end{array}$ \\
\hline Inflation & + & - & $?$ & $?$ & - \\
GDP growth & + & + & $?$ & $?$ & - \\
Real Credit & $?$ & $?$ & + & - & $?$ \\
Prime Spread & $?$ & $?$ & + & + & $?$ \\
Selic & $?$ & $?$ & $?$ & $?$ & + \\
\hline
\end{tabular}

Source: Author's elaboration. 
Figure 4 - Impulse Responses
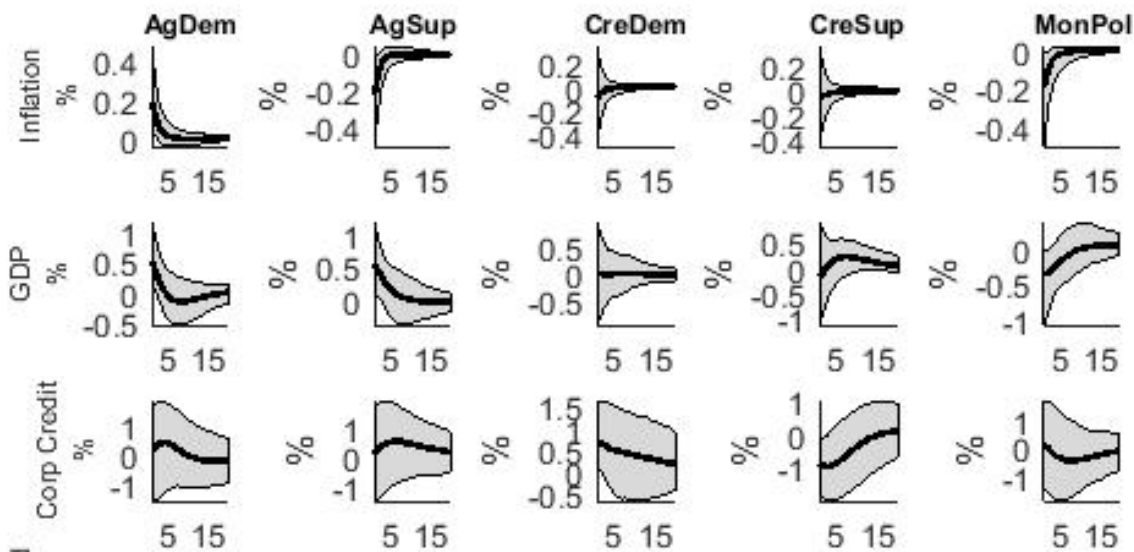

515

515
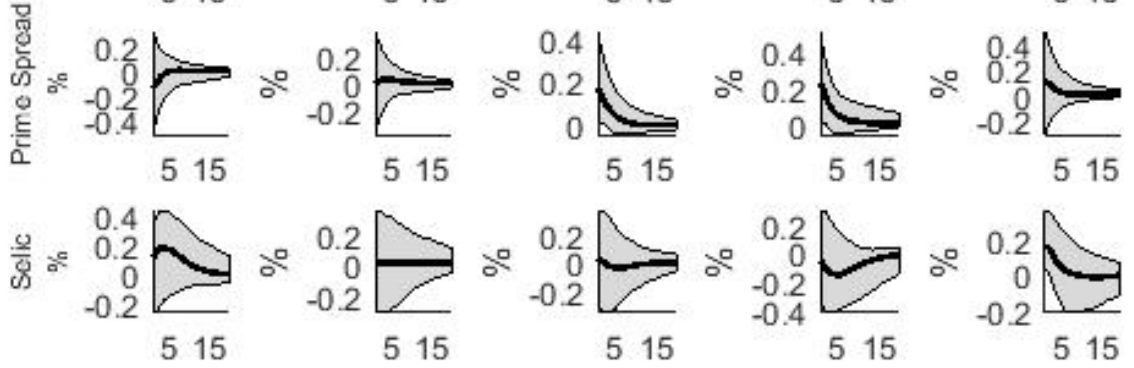

Source: Author's elaboration.

Note: AgDem: aggregate demand shock, AgSup: aggregate supply shock, CreDem: credit demand shock, CreSup: credit supply shock, MonPol: monetary policy shock

\subsection{Monthly Data}

The results present in the previous sections could be influenced by the short sample period. To try to overcome this issue, this section shows the results on a monthly frequency. The sample period now runs from March 2007 to July 2017, 125 observations. The monthly activity index of the Central Bank is used to replace the real GDP growth series. All other variables are the same as in Figure 1, although at the monthly frequency.

In this case, each model was estimated with 4 lags. Each shock lasts for 6 months, in the same way as in the quarterly frequency models.

\subsubsection{Credit Supply Shocks}

The impulse response is shown on Figure 5. A credit supply shock is represented by an increase in the prime spread and fall in real corporate credit volume. 
Economic activity, proxied by the IBC-BR index, remains almost flat after the shock. Inflation also shows a negligible response. Monetary policy reacts endogenously through a cut in the Selic rate.

Figure 5 - Impulse response function of a credit supply shock
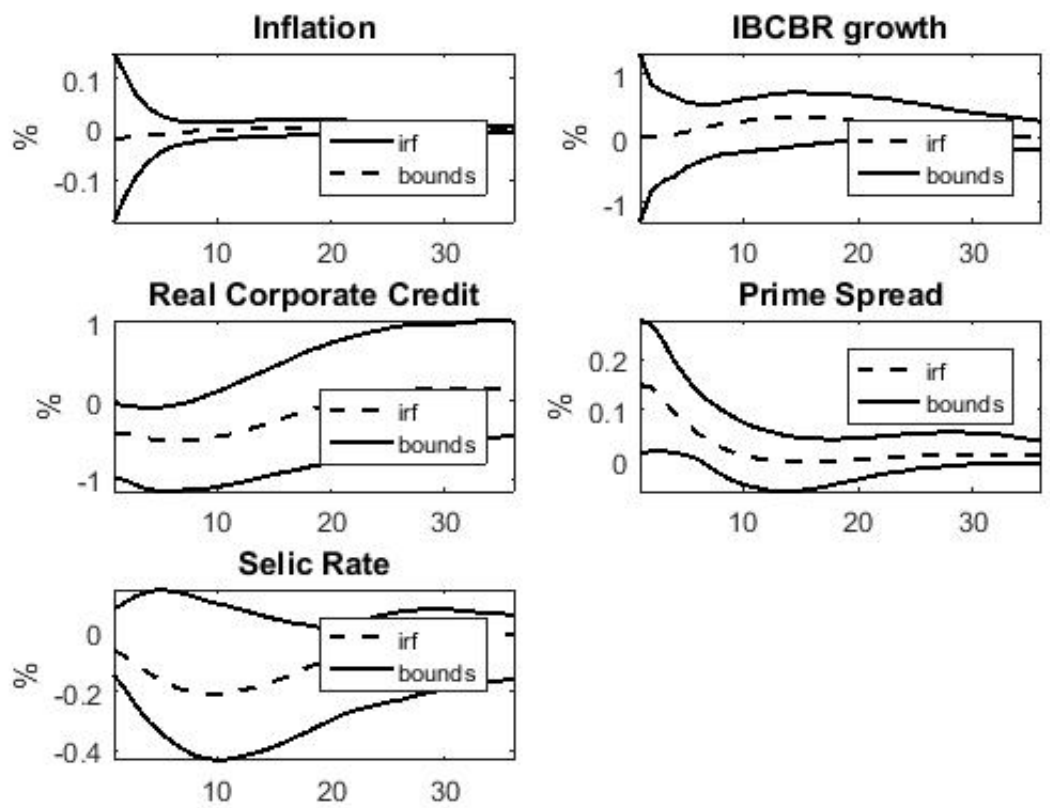

Source: Author's elaboration.

\subsubsection{Monetary Policy Shock with Bank Lending Channel}

This shock, presented on Figure 6 is represented by a hike in the Selic rate followed by an increase in the prime spread and fall in the outstanding credit. Again the responses of inflation and economic activity are quite small. 
Figure 6 - Impulse response function of a monetary policy shock with bank lending channel
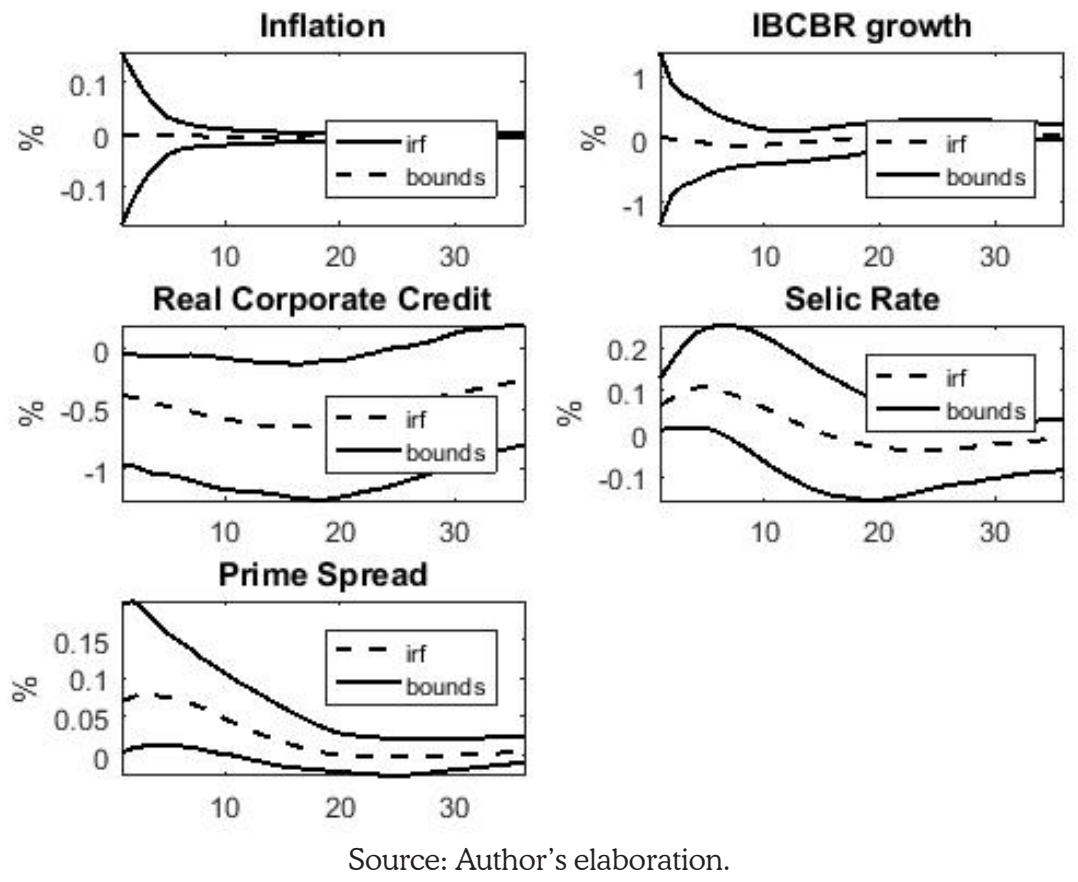

\subsection{Probability of Negative GDP growth}

Rather than showing the impulse response functions, this section presents the probability of observing negative GDP growth after a standard shock that lasts for 2 quarters. To answer this question, the impulse response of GDP growth is restricted to negative for a given number of quarters, and the acceptance rate is computed for several models. This exercise was motivated by the fact the identification method (BVAR with sign restrictions) produce a set of impulse responses that can be compatible with different models, so that the median impulse response cannot be produced by a single set of model parameters (FRY; PAGAN, 2007).

Results are presented on Table 2 . The probability of observing negative GDP growth after these kind of shocks is around $5 \%$ at the one year horizon. 
Table 2 - Probability (Acceptance rate) of negative GDP growth after a shock

\begin{tabular}{c|c|c}
\hline Quarters & Credit Supply & Bank Lending \\
\hline 1 & $5.64 \%$ & $4.81 \%$ \\
2 & $5.07 \%$ & $4.67 \%$ \\
3 & $3.96 \%$ & $4.58 \%$ \\
4 & $2.93 \%$ & $4.35 \%$ \\
5 & $1.70 \%$ & $3.70 \%$ \\
6 & $1.08 \%$ & $3.05 \%$ \\
\hline
\end{tabular}

Source: Author's elaboration.

\section{The Role of Credit Supply Shocks in Economic Fluctuations in Brazil}

This section shows the role of credit supply shows in Brazilian business cycles. For this end, it is presented both the forecast error variance decomposition and the historical decomposition of output growth of the model in section 4.1.3 that include aggregate demand and supply shocks, supply and demand credit shocks and monetary policy shocks.

While the forecast error variance decomposition shows the average contribution over the sample period, the historical decomposition traces the contribution of each shock to GDP growth over time.

Table 3 shows the forecast error variance decomposition of GDP growth. Credit supply shocks respond to roughly $12 \%$ of GDP growth variability after the first quarter. But these shocks gain importance over time, reaching $22 \%$ of the forecast error variance of GDP growth after 3 years, larger than the other shocks. In turn, credit demand shocks account for around 12\% of GDP variability over time. Aggregate demand and supply shocks respond for around $20 \%$ of GDP variability in the long run. Monetary policy shocks show an increased role over time, with its share almost doubling from $8 \%$ to $15 \%$ in the long run. 
Table 3 - Forecast error variance decomposition of GDP growth

\begin{tabular}{cccccc}
\hline Quarters & $\begin{array}{c}\text { Aggregate } \\
\text { Demand }\end{array}$ & $\begin{array}{c}\text { Aggregate } \\
\text { Supply }\end{array}$ & $\begin{array}{c}\text { Credit } \\
\text { Demand }\end{array}$ & $\begin{array}{c}\text { Credit } \\
\text { Supply }\end{array}$ & $\begin{array}{c}\text { Monetary } \\
\text { Policy }\end{array}$ \\
\hline 1 & $18 \%$ & $18 \%$ & $9 \%$ & $12 \%$ & $8 \%$ \\
5 & $15 \%$ & $20 \%$ & $11 \%$ & $16 \%$ & $13 \%$ \\
10 & $18 \%$ & $20 \%$ & $12 \%$ & $20 \%$ & $14 \%$ \\
15 & $19 \%$ & $20 \%$ & $12 \%$ & $22 \%$ & $14 \%$ \\
20 & $19 \%$ & $20 \%$ & $12 \%$ & $22 \%$ & $15 \%$ \\
\hline
\end{tabular}

Source: Author's elaboration.

Note: "Median values.

Figure 7 presents the historical decomposition of GDP growth in Brazil, with the slowdown in GDP growth being mainly due to exogenous shocks in the model. ${ }^{4}$

Figure 7 - Historical decomposition

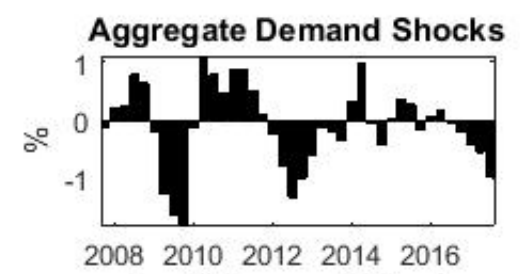

Credit Demand Shocks

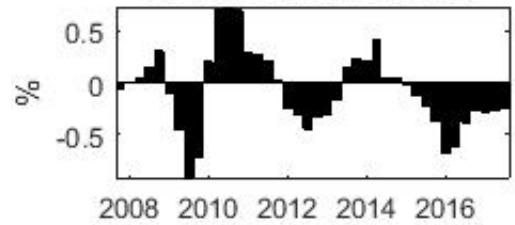

Monetary Policy Shocks

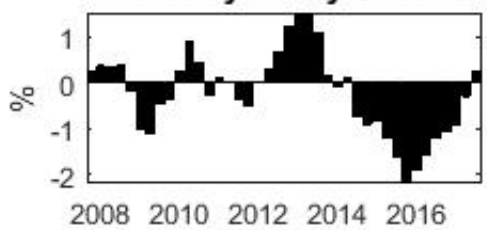

Aggregate Supply shocks

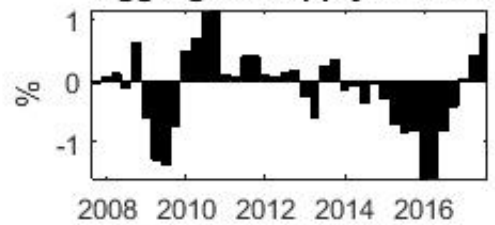

Credit Supply Shocks

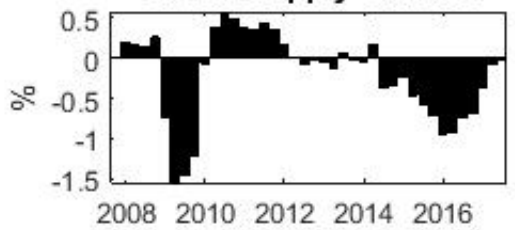

Exogenous Shocks

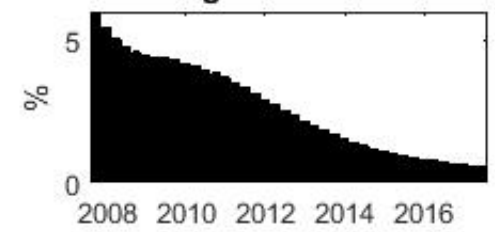

Source: Author's elaboration.

Figure 8 focuses on the contribution of credit spread shocks to GDP growth. Credit spread shocks contributed very negatively to GDP growth during the GFC,

$4 \quad$ This is a closed-economy model, so exogenous shocks may capture terms of trade and world economy shocks, and also numerous non-economic shocks that hit the economy since 2014, as anticorruption investigations and political shocks more generally. 
from $2008 \mathrm{Q} 4$ to $2009 \mathrm{Q} 4$. The contribution turned to positive between $2010 \mathrm{Q} 1$ and $2011 \mathrm{Q} 4$, in the aftermath of the GFC. The period between 2012 and 2013 marked a small, overall negative contribution of prime spreads to GDP growth. Shocks on the prime spread contributed to the slowdown of the economy since 2010, but it is unlikely to have been the main factor. Since $2014 \mathrm{Q} 2$, the contribution of credit spread shocks to GDP growth has been negative, with the long deterioration of the credit market after the recession, with a different dynamics than the 2008/2009 recession, which was much shorter.

Figure 8 - Contribution of credit supply shocks to GDP growth

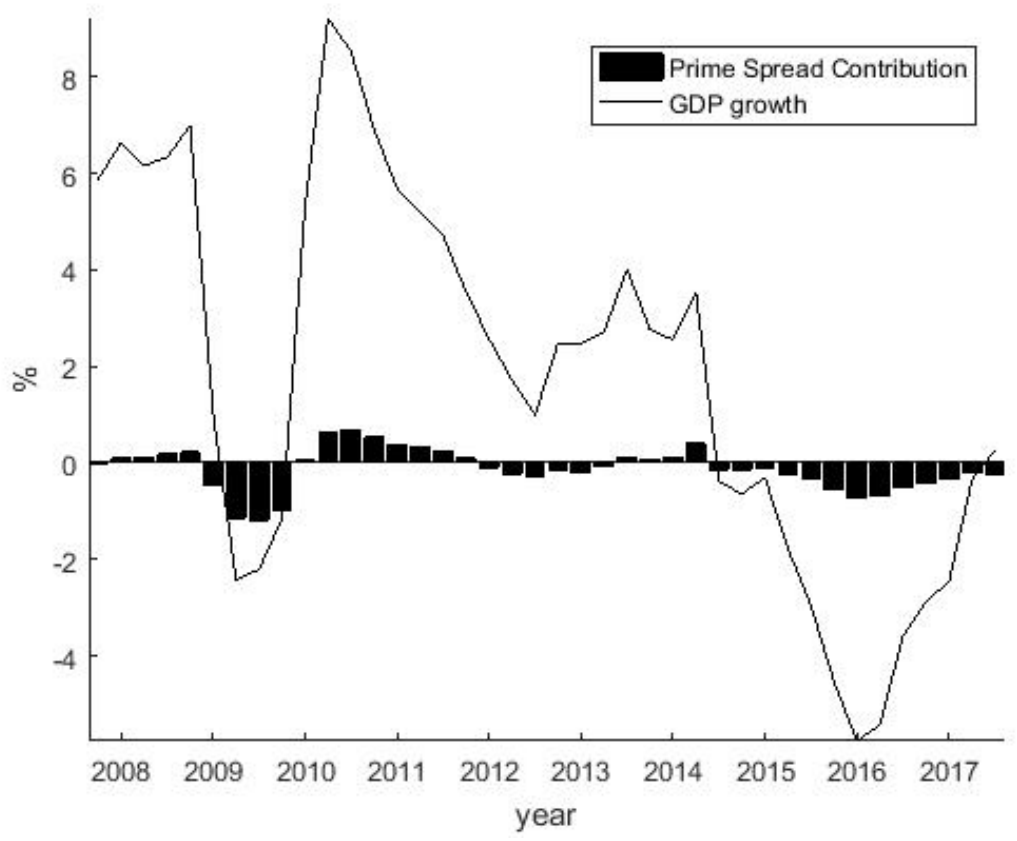

Source: Author's elaboration.

The historical contribution of GDP growth shows that the GFC was transmitted to Brazil mainly through negative aggregate demand shocks. Credit supply and to a lesser extent monetary policy shocks also contributed negatively to the recession.

In turn, the model interprets the 2014-2016 recession predominantly with negative aggregate supply and monetary policy shocks. The onset of the recession was driven by negative supply shocks, with negative contributions since the end of 2013. The model explains the gradual recovery through a positive contribution of aggregate supply shocks since 2016Q4 and monetary policy shocks since 2017Q2, 
while the other shocks are still contributing negatively, although less than in the trough of the recession. The estimated structural shocks are on Figure 9.

Figure 9 - Structural shocks
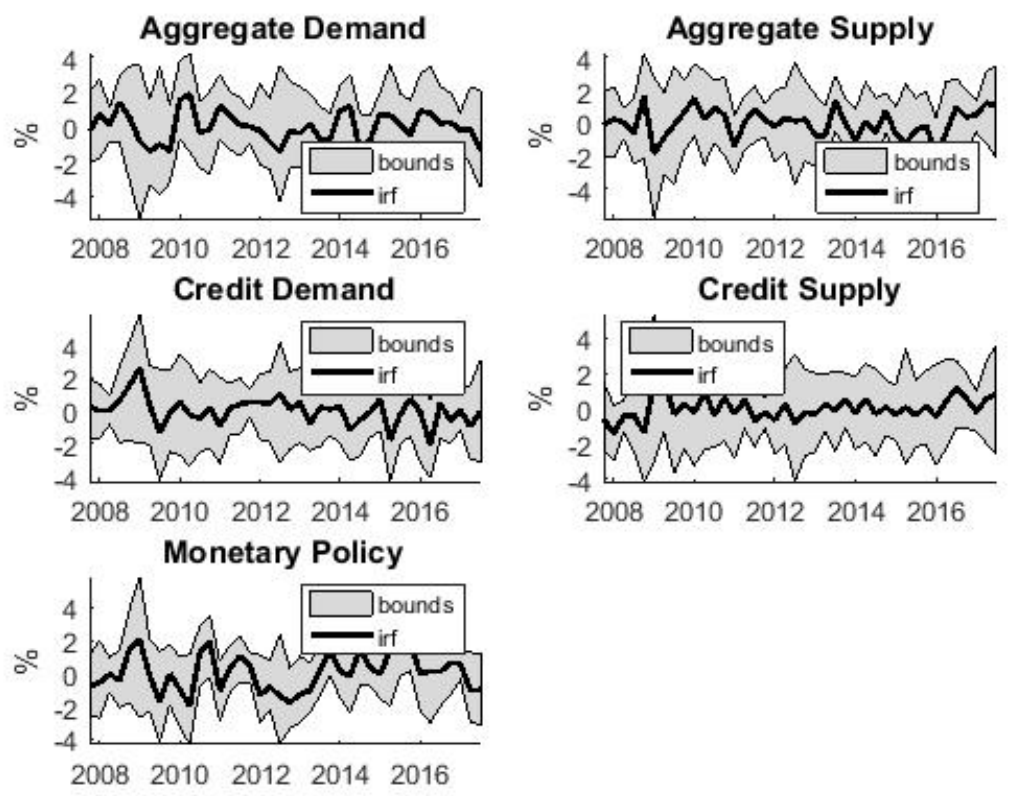

Source: Author's elaboration.

\section{Final Considerations}

This paper studied the role of credit supply shocks in Brazil, using a BVAR with sign restrictions. It therefore contributes to the literature, in light of the growing research on this topic for other countries. Since Brazil experienced a substantial process of credit deepening over the last decade, a natural question that arises is how the economy would respond to a credit supply shock.

It was found that negative credit supply shocks, both pure or in association with the bank lending channel of monetary policy, produce mild responses in output growth and inflation, in contrast to the findings for other countries. Considering the impulse responses, credit supply shocks were found to be relatively less important in Brazil relative to the results obtained for other countries. For instance, Duchi and Elbourne (2015) for the Netherlands, Barnett and Thomas (2014) for the UK, Halvorsen and Jacobsen (2014) for Norway and UK, Peersman (2012), Bijsterbosch and Falagiarday (2014) and Aldasoro and Unger (2017) for the euro area, Gilchrist and Zakrajsek (2012b) for the US, Gambetti and Musso (2016) for 
the US, UK and euro area, all found sizeable declines of real GDP after a standard credit supply shock in the respective countries.

The forecast error variance decomposition of GDP growth shows that these type of shocks respond each for little more than $12 \%$ of the short term variance decomposition of GDP growth in Brazil, although in the long run prime spread shocks become more important, responding for $22 \%$ of GDP growth variability. This figure compares with the 20-25\% found for Norway and UK in Halvorsen and Jacobsen (2014), 20\% for the US in Meeks (2012) and also 20\% for the euro area in Aldasoro and Unger (2017), showing the importance in the long run of shocks stemming from the financial intermediation sector in Brazil, in line with that of developed countries.

The related literature generally reports a major role for positive credit supply shocks in the run up to and overall negative credit supply shocks in the aftermath of the GFC. For Brazil, the historical decomposition of GDP growth shows that credit supply shocks exerted a substantial negative contribution to GDP growth around the time of the GFC, consistent with the results for other countries. Prime spread shocks contributed to the slowdown of the economy after 2010. Between 2012 and 2013, the contribution was small, in the context of expansionary policies, and has shifted to negative since $2014 \mathrm{Q} 2$, with the deterioration of the credit market brought by the recession. These results are consistent with the view that credit shocks do no matter in normal times but in extreme periods it can matter a lot, and that when recessions coincides with substantial declines in credit, they tend to become deeper (HELBLING et al., 2011).

A possible explanation for the low sensitivity of output to credit supply shocks in Brazil in the impulse responses is the presence of a dual credit market in Brazil, with half of the credit market not subject to oscillations in market credit spreads considered in the econometric analysis presented in this paper. If this interpretation is correct, the ongoing unification of parts of the credit market in Brazil will likely result in an increased role of credit supply shocks as drivers of the business cycles in the country.

\section{References}

ALDASORO, I.; UNGER, R. External financing and economic activity in the euro area: why are bank loans special? [S. 1]: Bank for International Settlements, 2017. (BIS Working Papers, n. 622).

ATTA-MENSAH, J.; DIB, A.Bank lending, credit shocks, and the transmission of Canadian monetary policy. International Review of Economics 8 Finance, v. 17, n. 1, p. 159-176.2008.

BARNETT, A.; THOMAS, R. Has weak lending and activity in the United Kingdom been driven by credit supply shocks? The Manchester School, v. 82, n. S1, p. 60-89, 2014. 
BERNANKE, B. S.; GERTLER, M.; GILCHRIST,S. The financial accelerator in a quantitative business cycle framework. In: TAYLOR, J. B.;WOODFORD, M. (Ed.). Handbook of macroeconomics. Amsterdam: Elsevier, 1999. p. 1341-1392. v. 1.

BIJSTERBOSCH, M.; FALAGIARDAY, M. Credit supply dynamics and economic activity in euro area countries: a time-varying parameter VAR analysis. Frankfurt: European Central Bank, 2014. (ECB Working Paper n. 1714).

BONOMO, M.; BRITO, R.; MARTINS, B. The after crisis government-driven credit expansion in Brazil: a firm level analysis. Journal of International Money and Finance, v. 55, p. 111-134, 2015.

CALDARA, D.; HERBST, E. Monetary policy, real activity, and credit spreads: evidence from Bayesian proxy SVARs. Washington: Board of Governors of the Federal Reserve System, 2016. (Finance and Economics Discussion Series, n. 049).

CARVALHO, C.et al. Macroeconomic effects of credit deepening in Latin America. [S. 1.], 2018. Disponível em:<http://dx.doi.org/10.2139/ssrn.2503755>. Acesso em: 23 jun. 2019.

COELHO, C.A.et al. Identifying the bank lending channel in Brazil through data frequency. Economía, v. 10, n. 2, p. 47-79, 2010.

DIEPPE, A.; LEGRAND, R.; VAN ROYE,B. The BEAR toolbox. Frankfurt: European Central Bank, 2016. (Working Paper Series, n. 1934).

DUCHI, F.; ELBOURNE, A. Credit supply shocks in the Netherlands. Journal of Macroeconomics, v. 50, n. C, p. 51-71, 2016.

FRY, R.; PAGAN, A. Sign restrictions in structural vector autoregressions: acritical review. Journal of Economic Literature, v. 49, n. 4, p. 938-960, 2011.

GAMBETTI, L.; MUSSO, A. Loan supply shocks and the business cycle. Journal of Applied Econometrics, v. 32, n. 4, p. 764-782, 2016.

GILCHRIST, S.; ZAKRAJSEK, E. Bank lending and credit supply shocks. In: ALLEN, F. et al. (Ed). The global macro economy and finance. London: Palgrave Macmillan, 2012a.p. 154-176.

GILCHRIST, S.;ZAKRAJŠEK, E. Credit supply shocks and economic activity in a financial accelerator model. In: BLINDER, A.; LO, A.; SOLOW, R. (Ed.). Rethinking the financial crisis. New York: Russell Sage Foundation, 2012b. p.37-72.

HALVORSEN, J. I.; JACOBSEN, D. H. How important can bank lending shocks be for economic fluctuations? The North American Journal of Economics and Finance, v. 29(C), p. 104-123, 2014.

HELBLING, T. et al. Do credit shocks matter? A global perspective. European Economic Review, v. 55, n.3, p. 340-353, 2011.

HRISTOV, N.; HÜLSEWIG, O.; WOLLMERSHÄUSER,T. Loan supply shocks during the financial crisis: evidence for the Euro area. Journal of International Money and Finance, v. 31 , n.3, p. 569-592, 2012. 
KANCZUK, F. Um termômetro para as macro-prudenciais. Revista Brasileira de Economia, Rio de Janeiro, v. 67, n. 4,p. 739-764, 2013.

MEEKS, R. Do credit market shocks drive output fluctuations? Evidence from corporate spreads and defaults. Journal of Economic Dynamics and Control, v. 36, n.4, p. 568-584, 2012.

MELLO, L.; PISU, M. The bank lending channel of monetary transmission in Brazil: a VECM approach. Quarterly Review of Economics and Finance, v. 50, n. 1, p. 50-60, 2010.

OLIVEIRA, F. N.; ANDRADE NETO, R. M. A relevância do canal de empréstimos bancários no Brasil. Revista Brasileira de Finanças, Rio de Janeiro, v. 6, n. 3, p. 357-409, 2008.

PEERSMAN, G. Bank lending shocks and the Euro area business cycle. Ghent: Ghent University, 2012. (Ghent University Working Paper, n. 11/766).

RAMOS-TALLADA, J. Bank risks, monetary shocks and the credit channel in Brazil: identification and evidence from panel data. Journal of International Money and Finance, v. 55(C), p. 135-161, 2015.

SOUZA SOBRINHO, N. F. Uma avaliação do canal de crédito no Brasil. Rio de Janeiro: BNDES, 2003.

TAKEDA, T.; ROCHA, F.; NAKANE, M. I. The reaction of bank lending to monetary policy in Brazil. Revista Brasileira de Economia, Rio de Janeiro, v. 59, n. 1, p. 107-126, 2005.

UHLIG, $\mathrm{H}$. What are the effects of monetary policy on output? Results from an agnostic identification procedure. Journal of Monetary Economics, v. 52, n. 2, p. 381-419, 2005.

\section{Appendix A - Corporate and Households Credit Supply Shocks}

This paper relied largely on movements in the prime rate to identify shocks in the Brazilian credit market, due to the similar risk profile embodied in the prime rate. Nevertheless, one may argue that the prime rate is not sufficient to identify shocks in the credit market, as credit shocks to consumers are also very important, and since the first quarter of 2016 the outstanding credit to households is actually larger than the outstanding credit to corporations. This section use the average spreads to corporations and households to identify credit supply shocks, even though these spreads mix different risk profiles among corporations and households. Two additional BVAR models were estimated, from March 2011 to July 2017, encompassing 77 observations, with normal-diffuse priors. The sample mainly reflects availability from the Central Bank database. The models included each 4 lags. As before, the sign restrictions are implemented so that the shock, identified as an increase in spread and a fall in the real credit volume, lasts for 6 months.

Results are shown in Figures 10 and 11. The shocks lead to almost negligible movements in economic activity, proxied by growth of the monthly activity index of the Central Bank. 
Figure 10 - Corporate credit supply shocks
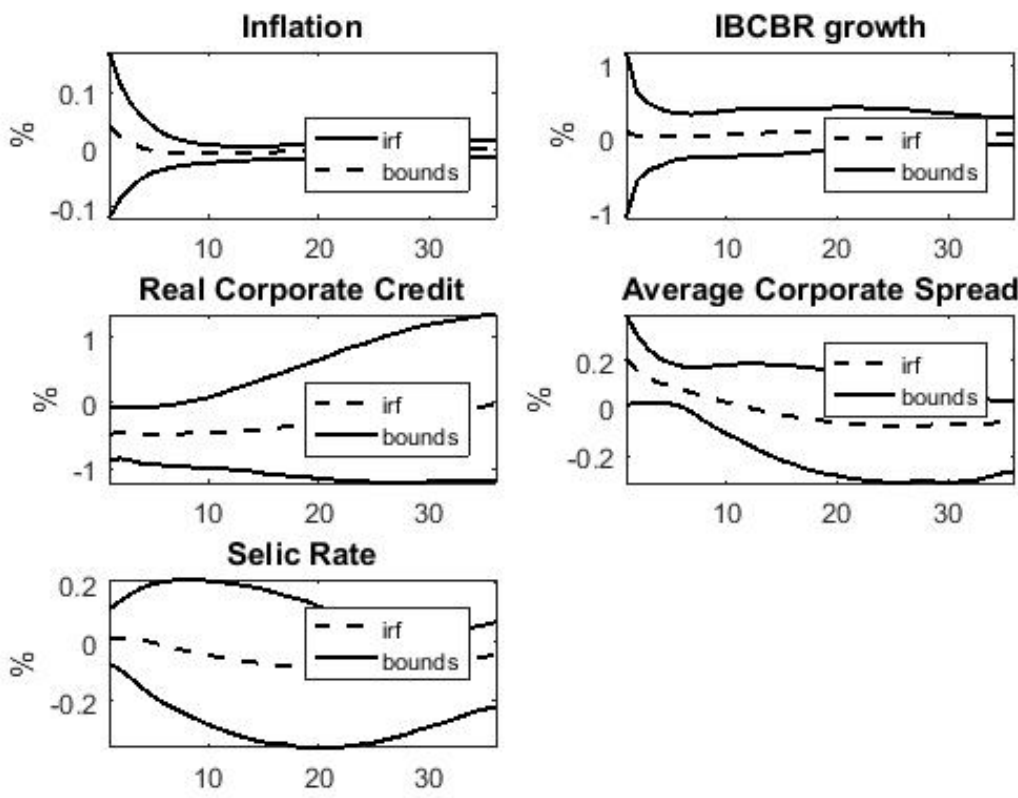

Source: Author's elaboration.

Figure 11 - Households credit supply shocks
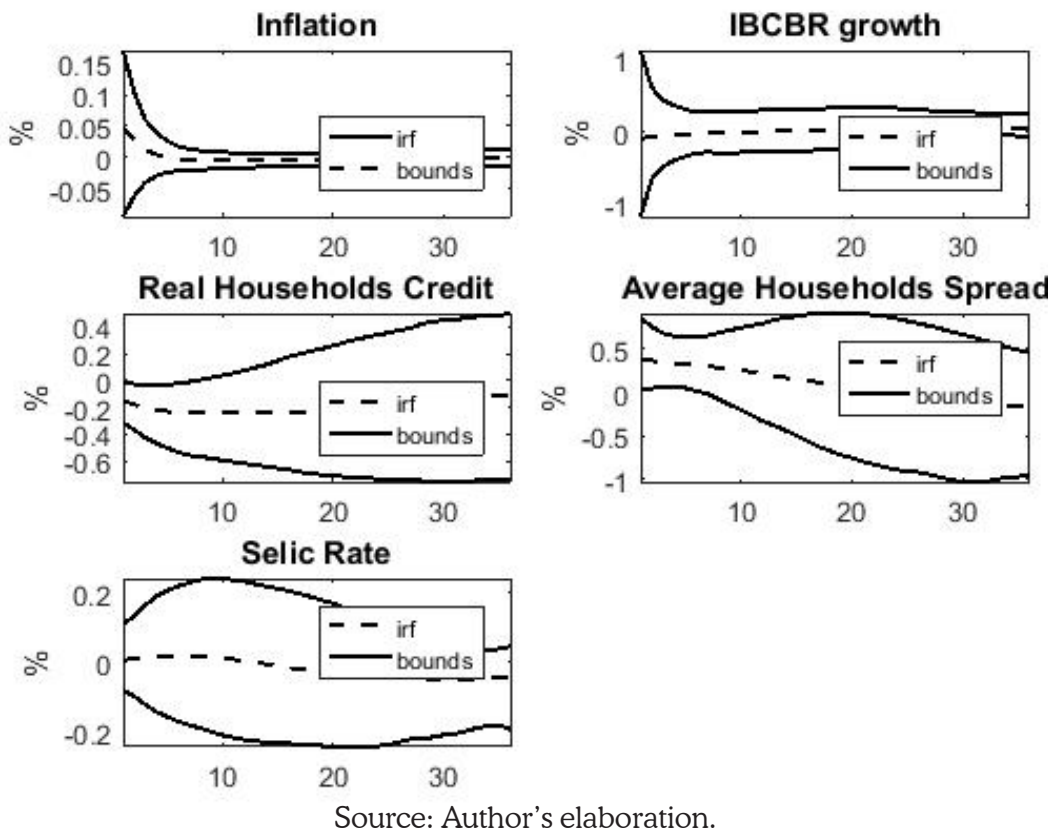


\section{Appendix B - Credit Supply Shocks on GDP level}

The results in the paper are based on models using yoy GDP growth rates. This section presents a robustness exercise, with a model using log of GDP instead of GDP growth rates. Figure 12 shows that after a prime spread shock, real GDP falls by less than $0.5 \%$, recovering gradually afterwards.

Figure 12 - Credit supply shocks on GDP level
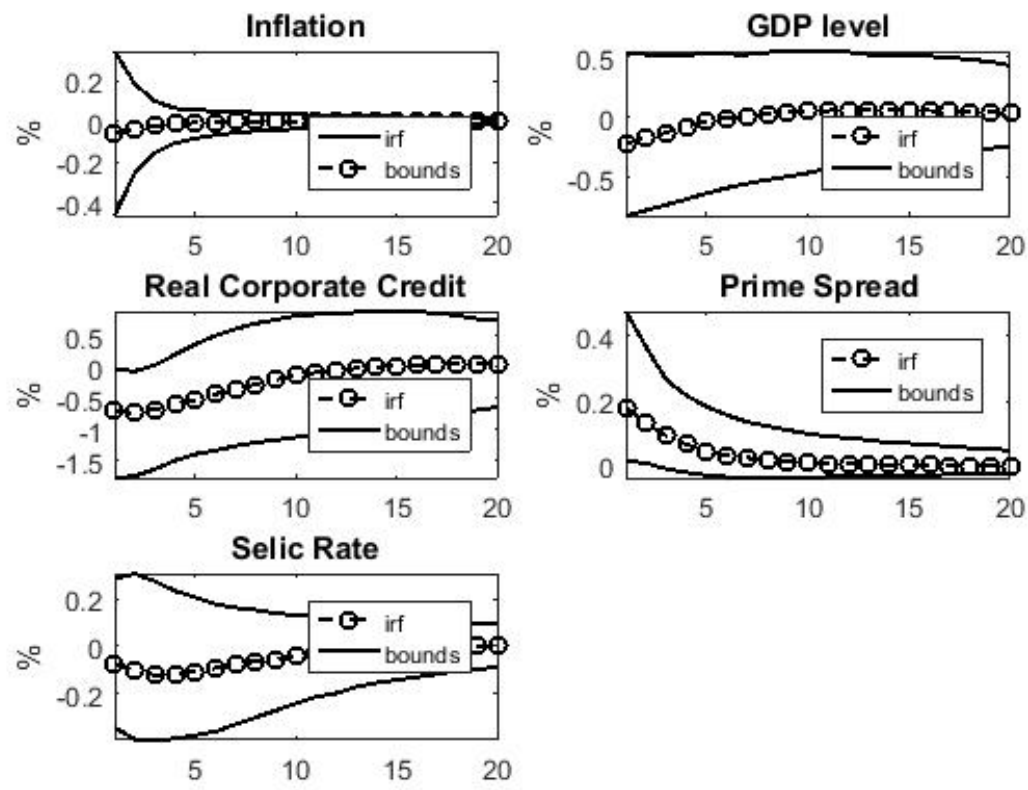

Source: Author's elaboration.

\section{Appendix C - Positive Credit Supply Shock}

This section presents the impulse response function of a positive credit supply shock, associated with an increase in the real corporate credit and a decrease in the prime spread. Due to the linearity of the model, the results of this shock are similar to a negative supply shock, but with opposite outcomes relative to a negative credit supply shock. 
Figure 13 - Positive credit supply shocks
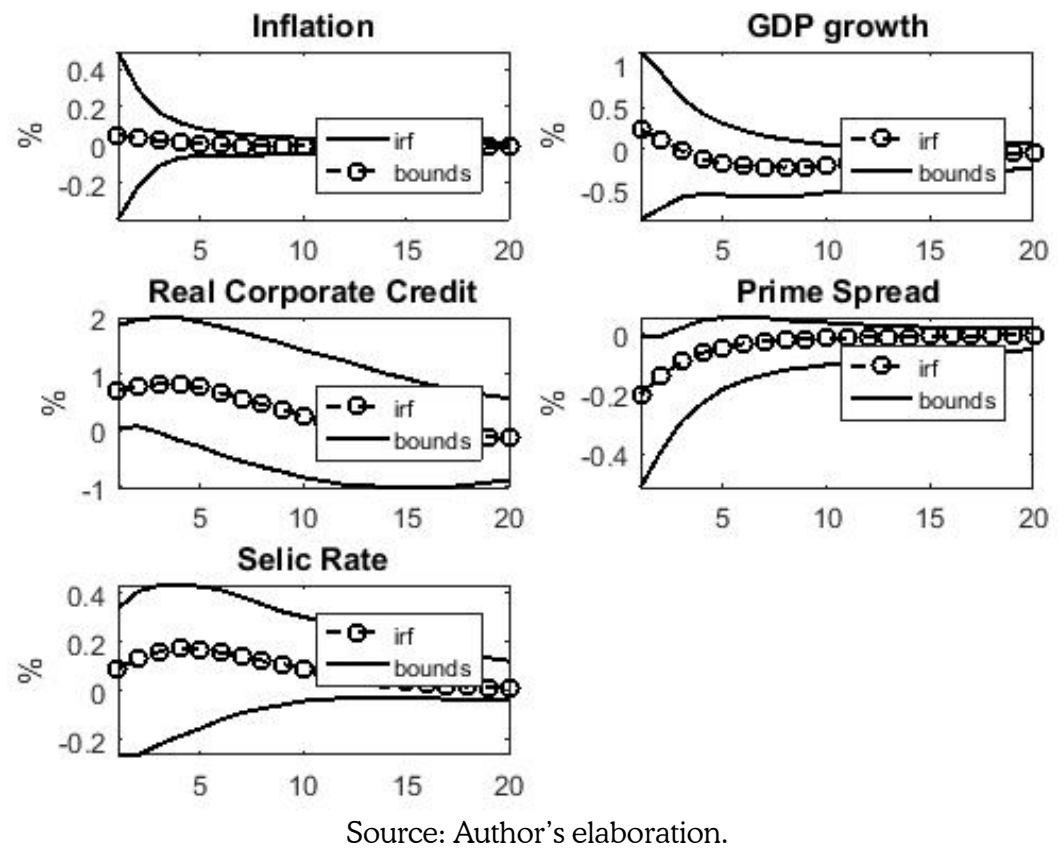